УДК 37 (091) (477)

DOI: $10.35619 /$ iiu.v1i10.150

Грона Наталія

доктор педагогічних наук, голова циклової комісії викладачів української мови і літератури Прилуцького гуманітарно-педагогічного коледжу ім. І. Я. Франка,

м. Прилуки, Україна

ORCID: 0000-0003-2578-2865

e-mail: natashagrona@ukr.net

\title{
ВЛАСНЕ ВИСЛОВЛЕННЯ: МОВНА НОРМАТИВНІСТЬ У КОНТЕКСТІ ІДЕЙ В. О. СУХОМЛИНСЬКОГО
}

Анотація. Стаття акцентує увагу на актуальності педагогічних ідей В. О. Сухомлинського в контексті проблем дотримання мовних норм у власних висловленнях учасників зовнішнього незалежного оцінювання. Наголошено на необхідності та важливості використання поглядів педагога щодо вивчення української мови. Слушними є думки В. О. Сухомлинського, який радить вдумливо й багато працювати над тим, аби слово жило в дитячій творчості, у спілкуванні, бо вважав це однією з умов загальної та педагогічної культури шкільного життя.

Автор вважає, що створення досконалих текстів $\epsilon$ складним аналітикосинтетичним процесом, спрямованим на досягнення результату пізнавальної діяльності.

Доведено, що процес підготовки до створення власних висловлень не можна вважати достатнім, якщо учнів/студентів не залучено до практичної діяльності 3 вивчення та вдосконалення мовних норм. Тому, щоб запобігти вживанню лексичних і граматичних анормативів у текстах-роздумах, доцільно застосовувати на заняттях різноманітні мовні вправи.

Аби правильно орієнтувати здобувачів освіти у виборі мовних засобів, педагог має бути добре обізнаним із сучасними процесами розвитку мови, труднощами, які виникають у засвоєнні учнями/студентами знань про норми української літературної мови, уміло застосовувати різноманітний комплекс методів.

Науковий пошук дав можливість виокремити провідні напрями роботи для формування норм літературної мови як еталона правильності мовлення, основної умови реалізації найважливішої функції мови - комунікативної.

Спираючись на ідеї В. О. Сухомлинського, ми переконалися, що українська мова має виразні індивідуальні риси на різних мовних ярусах, тому анормативи $\epsilon$ свідченням недостатнього опанування мовних норм.

Ключові слова: педагогічні ідеї В. О. Сухомлинського, зовнішнє незалежне оцінювання, власне висловлення, текст, мовні норми, анормативи, лексичні, граматичні помилки, мовні вправи.

Постановка проблеми. В умовах динамічного розвитку сучасної української мови, іiї дослідження в контексті дискурсу, інтеграції та інформатизації гуманітарної освіти і водночас недостатньої суспільної уваги до ідентифікувальної, об'єднувальної ролі української мови, випадків порушення эї норм в офіційних і неофіційних сферах спілкування зумовлює докорінне переосмислення освітньої парадигми, актуалізації змісту, розроблення технологій мовної підготовки учня/студента. Тому на державному рівні впродовж 2014-2019 років для розвитку української мови зроблені важливі кроки: оновлені навчальні програми, запроваджено зовнішнє незалежне оцінювання 3 української мови як обов'язкове, ухвалено закон «Про забезпечення функціонування української мови як державної» (2019). Однак кількість учнів, які не складають цей 
іспит, зростає. Зокрема, у 2014 році таких було лише ледь більше за 9\%, а от у 2019 уже $16 \%$.

Тому на часі погляди В. О. Сухомлинського, який вважав, що рідна мова - це мова, 3 якою людина входить у світ, прилучається до загальнолюдських цінностей, тож вона має вивчатися постійно й глибоко. Він стверджував, що рідна мова - це - «духовне багатство народу», у якому народ живе, передає 3 покоління в покоління свою мудрість і славу, культуру і традиції (Сухомлинський, 1977, с. 201). Великий педагог підкреслював красу й особливість рідного слова: «Чим глибше людина пізнає тонкощі рідної мови, тим тонша їі сприйнятливість до гри відтінків рідного слова, тим більше підготовлений ії розум до оволодіння мовами інших народів, тим активніше сприймає красу слова» (Сухомлинський, 1977, с. 201-202). Опанування рідної мови, рідного слова започатковується в ранньому дитинстві, а її вдосконалення, засвоєння культури триває протягом усього життя.

Саме таке ставлення до української мови формує здатність до продуктивної комунікації, підвищує рівень мовної грамотності учнів та студентів під час написання різних творчих робіт, що набуває особливої актуальності на сьогодні. Адже окрім виконання «чистих» тестових завдань, учасники зовнішнього незалежного оцінювання (ЗНО) створюють власне висловлення (відкрите тестове завдання) стосовно проблеми, порушеної в мікротексті-темі. Метою відкритого тестового завдання в тесті ЗНО 3 української мови та літератури є об'єктивне виявлення здатності учасника тестування самостійно в писемній формі висловлювати свої думки стосовно визначеної актуальної проблеми сьогодення у вигляді закінченого тексту 3 дотриманням норм сучасної української літературної мови (орфографічних, пунктуаційних, лексичних, граматичних, стилістичних). Учасник тестування, виконуючи відкрите тестове завдання, повинен показати рівень сформованості в нього навичок: ефективного використання знань української літературної мови на практиці; критичного мислення 3 окремих проблем, актуальних для молоді. Своєрідність власного висловлення як різновиду твору-роздуму зумовлена тим, що учасник тестування у власному висловленні повинен не просто поміркувати над запропонованою темою, а довести виправданість своєї позиції стосовно відповідної теми, обгрунтувати свою думку, аргументувати прикладами, написати текст, керуючись не власними уявленнями про його тему, а дотримуючись вимог, визначених в умові відкритого тестового завдання.

Для того, аби учень/студент зумів висловити думку, дотримуючись вимог композиційного плану та мовного оформлення, потрібна копітка й цілеспрямована робота вчителя/викладача. Слушними є думки В. О. Сухомлинського, який радить вдумливо й багато працювати над тим, аби слово жило в дитячій творчості, у спілкуванні, бо вважав це однією з умов загальної та педагогічної культури шкільного життя. Його уроки мислення серед природи, технологія створення казок були насамперед уроками розвитку дитячого мислення й мовлення. Під час їхнього проведення думка школярів поступово ставала дедалі яскравішою, багатшою, виразнішою, слово набувало емоційного забарвлення, а в учителів з'являлася можливість учити дітей думати.

Аналіз останніх досліджень 3 проблеми. Нова парадигма філософії освіти України XXI ст. вимагає перегляду й модернізації чинних стандартів освіти на всіх іiі ланках. У концепції реформування загальної середньої освіти «Нова українська школа» (2016 р.) передбачено не тільки оновлення змісту освіти, а й організацію освітнього процесу в цілому, зокрема провідним $\epsilon$ компетентнісний підхід у навчанні. У цьому вимірі серед 10-ти ключових компетентностей, які мають набути учні під час вивчення різних предметів на всіх етапах освіти, $є$ спілкування українською мовою. Це вміння усно і письмово висловлювати й тлумачити поняття, думки, почуття, факти та погляди (через слухання, говоріння, читання, письмо, застосування мультимедійних засобів), здатність реагувати мовними засобами на повний спектр соціальних i 
культурних явищ - у навчанні, на роботі, вдома, у вільний час, усвідомлення ролі ефективного спілкування (Експрес-порадник учителя НУШ, 2019, с. 19).

У науковому фонді в контексті досліджень (Н. Болотнова, Н. Валгіна, І. Гальперін, М. Доблаєв, М. Жинкін, І. Зимня, Ю. Караулов, О. Леонтьєв, А. Новиков, З. Тураєва та ін.) розкрито питання породження, сприймання і розуміння тексту; у працях Л. Варзацької, О. Глазової, Т. Ладиженської, М. Львова, М. Наумчук - студійовано методику навчання різних типів мовлення дітей молодшого шкільного віку; у наукових розвідках (В. Бадер, М. Вашуленко, Є. Голобородько, О. Горошкіна, В. Капінос, М. Пентилюк, О. Хорошковська, Г. Шелехова та ін.) окреслено основні методичні прийоми роботи 3 текстом. Ми вважаємо, що формування текстотворчих умінь учнів залежить від ефективного аналізу текстової інформації, визначення індивідуальних особливостей розуміння тексту під впливом різних контекстних (або ситуаційних чинників), пов'язаних із зовнішніми умовами перебігу процесів сприймання й розуміння тексту: просторово-часового чинника, форми роботи 3 текстом, способів його репрезентування, кількості учасників комунікації, наявності зовнішніх стимулів і настанов тощо. Створення досконалих текстів $\epsilon$ складним аналітико-синтетичним процесом, спрямованим на досягнення результату пізнавальної діяльності (Грона, 2017 , с. 26). Одним із критеріїв оцінювання тексту є мовно-мовленнєва вправність уміння використовувати лінгвістичні засоби відповідно до норм літературної мови, визначати функцію мовних одиниць відповідно до стилю, типу і жанру мовлення.

Український педагог М. В. Фоненко зазначав, що В. О. Сухомлинський багато уваги приділяв поліпшенню мовної грамотності учнів та вихованню любові до слова. Мовна культура людини - це дзеркало духовної культури. Слово вважається не тільки носієм потрібної інформації, воно $є$ ніби іскрою, від якої розгортається полум'я інтересу, тому воно повинно бути барвистим, образним і точним. Найтонший i найголовніший інструмент учителя - це слово в його руках. Він указував на те, що педагог має вибирати зі скарбниці мови саме ті слова, які відкривають шлях до людського серця, неповторного і не схожого на інші. Задля виховання словами, треба розвивати у вихованців сприйнятливість до слова (Заволока,1979, с.8-9). Звичайно, поза увагою не повинна бути й головна ознака літературної мови - унормованість, для якої обов'язкова правильність, точність, логічність, чистота та ясність, доступність і доцільність висловлення.

Проблема мовної норми, а отже правильності й ефективності вживання мовних одиниць, завжди буде дискусійною. Це зумовлено, по-перше, як суб'єктивністю тлумачення цього питання, так i, по-друге, об'єктивністю існування нечіткості у визначенні меж норми. Тому проблема нормативності мови доволі часто виходить 3 поля кодифікації, оскільки поняття правильності (неправильності) уживання чи написання мовної одиниці замінюється поняттям доцільності (недоцільності) такого вживання чи написання конкретною особою у визначеній ситуації. Мовну норму в лінгвістичних дослідженнях традиційно розглядають у контексті мовної системи, тому і визначають такими предикатами, як: пов'язана із системою, явище системи тощо.

Словниковий склад мови, лексичні норми, досліджували, починаючи з О. Потебні та I. Огієнка. Маємо фундаментальні праці Л. Булаховського, М. Жовтобрюха, А. Бурячка та ін.

Причинами відхилення від лексичних норм у мовній практиці може бути як незнання точного лексичного значення слова, так і невміння вибрати із синонімічного ряду найточніше значення. «Намагання до точності вислову, - зауважував український мовознавець Л. Булаховський, - веде за собою, насамперед, роботу над синонімікою: використовуються наявні слова та вирази, близькі одні до одних за змістом, але 3 певними відмінностями в значенні або емоційному забарвленні» (Булаховський, 1947, c. 97).

Однак, попри досягнення у галузі мовознавства і вітчизняної лексикографії, підвищення мовної грамотності учнів/студентів під час написання творів-роздумів 
набуває особливої актуальності на сьогодні, адже бракує адресованих школі праць 3 проблем унормування української літературної мови на засадах компетентнісного підходу, недостатньо приділено уваги аналізу мовних анормативів у висловлюваннях у форматі 3НО, не досить глибоко опрацьовані критерії виявлення помилок під час перевірки таких робіт.

Мета статті полягає у висвітленні окремих аспектів проблеми дотримання мовних норм у власних висловленнях й методів запобігання вживання анормативів на основі ідей В. О. Сухомлинського.

Виклад основного матеріалу дослідження. Основною й невід'ємною ознакою літературної мови $є$ їі унормованість. Норма має важливе суспільне значення з огляду на те, що вона забезпечує безперешкодне спілкування людей з різних регіонів України, мовлення яких характеризується діалектними особливостями. Дотримання норм літературної мови - еталон правильності мовлення, основна умова реалізації однієї 3 найважливіших функцій мови - комунікативної.

Володіння нормами української літературної мови та вміння доцільно добирати й застосовувати виражальні засоби мови вважають важливим складником мовленнєвої культури особистості, а отже - ії загальної культури.

Існує кілька визначень мовних норм, які можна узагальнити так: нормою називають сукупність найбільш стійких традиційних загальноприйнятих правил реалізації мовної системи, відібраних і закріплених у процесі суспільної комунікації; «закріплені в практиці зразкового використання мовні варіанти (у сфері вимови, слововживання, граматики, орфографії та пунктуації), які найкраще і найповніше 3поміж існуючих виконують свою соціальну роль» (Словник лінгвістичних термінів, 1985 , с. 156-157). Нормативність виявляється на рівнях мовної системи, тобто норми лексичні, фразеологічні, словотворчі, фонетичні (акцентологічні, орфоепічні) та граматичні (морфологічні й синтаксичні).

Читаючи творчі роботи учнів/студентів, ми насамперед перевіряємо рівень сформованості культури писемного мовлення, яке полягає в тому, щоб здобувачі освіти досконало знали мовні норми й послідовно дотримувалися їх. Письмові роботи, зокрема висловлення у форматі ЗНО, відображають орфографічні, лексичні, стилістичні, морфологічні, синтаксичні та пунктуаційні норми української мови.

Аналіз висловлень учнів/студентів дав можливість дійти висновку, що найпоширенішими є лексичні і граматичні анормативи. Наприклад, під час написання висловлення на тему «Як же вберегтися від зневіри на шляху до мрії?((3НО, 2019) ми прочитали такі «перли» (авторську орфографію та пунктуацію збережено): I мене бере гордість за мій вчинок. I я, скриплячи зубами, обрав правильний шлях. Я мріяв стати лікарем, щоб приносити усмішку на обличчя хворих. У наш час людство стало страмним. Спершу наші надії і сподівання супроводжують лише позитивні емоції, але майже в кінці фінішної прямої нас починають охоплювати сумніви.

Отже, це утверджує думку, що робота над усуненням таких помилок має бути корелятивною між рівнем теорії (норма, розуміння іï суті) і рівнем практики (формування компетентності під час виконання мовних вправ і завдань різного характеру).

Василь Олександрович Сухомлинський вважав, що успіх у навчанні багато в чому залежить від методів навчання. Дуже важливою умовою повноцінного розумового навчання $\epsilon$ відповідність методів навчання, структури уроку, організаційних елементів, завданням усебічного розвитку учнів. Проблемі методів навчання педагог приділяв велику увагу. У його дидактиці вона займала значне місце: «У світлі нових завдань, які постали нині перед школою в зв'язку з підготовкою вихованців до трудової діяльності проблема методів навчання набирає великого значення. Від умілого використання методів залежить не тільки міцність знань та практичних умінь і навичок, але і формування в учнів поглядів на знання, науку, виховання, бажання вчитись» (Сухомлинський, 1979, с. 17). Великого значення педагог приділяв методу вправ.

Він, маючи багаторічний досвід, дійшов висновку, що всі методи можна 4 
поділити на 2 групи: методи, які забезпечують первинне сприймання знань і вмінь учнями та методи осмислення, розвитку, поглиблення знань. До першої групи В. О. Сухомлинський відніс: розповідь, пояснення, лекцію, опис, тлумачення понять, інструктаж, бесіду, самостійне читання книг 3 метою первинного сприймання знань; демонстрацію, ілюстрацію (кіно, схеми, картини, телебачення, діаграми, макети, таблиці, муляжі, моделі); трудовий процес; самостійне спостереження, екскурсію, практичну і лабораторну роботи; процес самостійного оволодіння знаннями; показ фізичних вправ (Волошин, 2003, с.17). До другої групи він відніс: вправи (усні, письмові, технічні); пояснення факторів і явиш природи; дискусії, творчі письмові роботи (твори, реферати, анотації, складання задач, програмування), виготовлення навчальних посібників і приладів, графічні роботи, лабораторні роботи, експеримент (на навчально-дослідній ділянці, у лабораторії, кабінеті), керування машинами, механізмами, апаратами; тривала трудова діяльність, що поєднує мету практичної діяльності і мету вдосконалення вмінь, із поглиблення знань (у майстерні, на навчально-дослідній ділянці) (Волошин, 2003, с.17).

Отже, процес підготовки до створення власних висловлень не можна вважати достатнім, якщо учнів/студентів не залучено до практичної діяльності $з$ вивчення та вдосконалення норм.

Аналіз лексичних анормативів у роботах ЗНО дав можливість серед лексичних помилок i недоліків виокремити: невиправдані повтори слів, неточність слововживання, порушення лексичної сполученості слів, помилки в застосуванні фразеологізмів, похибки, які послаблюють емоційно-експресивну виразність тексту, одноманітність словника.

Для уникнення лексичних помилок (які полягають у неправильному вживанні слова чи кількох слів) у текстах-роздумах, пропонуємо на заняттях застосовувати різноманітні мовні вправи.

Відредагуйте словосполучення:

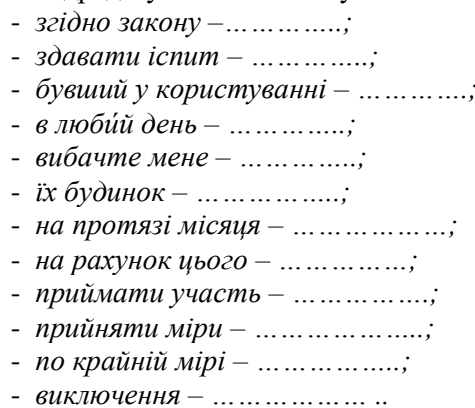

Виберіть правильний варіант лексичної сполучуваності: малочисленні/нечисленні випадки; працюємо біля/близько години; визволення/звільнення від загарбників; красномовний вираз/вислів; розкажи любу/будь-яку історію; оливкове(а) масло/олія; не дивлячись/незважаючи на негоду; здобувати/отримувати освіту; через кілька/пару хвилин; складати/становити п'ять відсотків; урок триває/продовжується 45 хвилин.

Обов'язково на занятті потрібно виділяти час на аналіз та пояснення умов правильного слововживання. Наприклад: «...поширену модель невідповідності значень ілюструє використання в науковому мовленні прикметника вірний і похідний від нього прислівника вірно, не враховуючи їхньої лексико-семантичної схеми валентності. Наприклад: сочіально вірний илях підлітка, сформульовано вірну відповідь, вірне написання слова, межі понять «вірно» $i$ «невірно», невірно визначені умови і под. Таке позанормативне слововживання можна пояснити впливом російської мови, де лексеми верный $і$ верно мають двоє основних значень: «відданий», «віддано»; «правильний», «правильно». 
Відповідно до «Великого тлумачного словника сучасної української мови» слово вірний має таку схему сполучуваності: вірний (відданий) друг, вірна (яка не зраджує) дружина, вірний (послідовний у поглядах) собі, вірна (несхибна) рука, вірна (неминуча) смерть (Великий тлумачний словник сучасної української мови, 2005, с. 152). А в значеннях «який відповідає дійсності, такий, як має бути; істинний», «який відповідає встановленим правилам, нормам» і «без помилок» потрібно вживати прикметник правильний і прислівник правильно: сочіально правильний шлях підлітка, сформульовано правильну відповідь, правильне написання слова, межі понять «правильно» $i$ «неправильно», неправильно визначені умови (Омельчук, 2019, с. 192). 3 огляду на це не можемо не процитувати I. Вихованця: «Пишімо правильно, а кохаймо вірно» (Вихованець, 2012, с. 111).

Значну кількість граматичних помилок знаходимо в роботах учасників ЗНО. У лінгводидактиці до групи граматичних помилок зараховують морфемні, словотвірні, морфологічні й синтаксичні порушення. До типових граматичних помилок відносять такі: морфемні й словотвірні - помилки, спричинені: а) уживанням нетипових для української мови (малопродуктивних, що витісняються іншими продуктивними засобами, чи зовсім не властивих мовній системі) словотворчих засобів, найчастіше суфіксів: атомшики, непередбачувальні, поставщиків, датчанин, не треба відчайдущуватись; б) порушенням закономірностей поєднання твірної основи й словотворчого засобу в похідному слові: подмінять, двохтрубне; морфологічні - помилки, що спричинені невідповідністю формального вираження якогось із граматичних значень тієї чи іншої повнозначної (самостійної) частини мови - роду, числа, відмінка, ступеня порівняння, особи, часу, способу, стану, виду. Залежно від частиномовної приналежності помилки виокремлюються такі різновиди морфологічних помилок: іменникові, прикметникові, числівникові, займенникові, прислівникові, дієслівні; синтаксичні - помилки, які спричинені незабезпеченням передбаченої граматичним ладом української мови побудови конструкцій (словосполучень, речень, надфразних єдностей) відповідно до усталених моделей синтаксичних зв'язків і відношень. Залежно від складності конструкції можуть бути виділені помилки на рівні: словосполучень, простих речень, складних речень, вищому за речення.

Серед тренувальних вправ, які запобігатимуть уживанню граматичних анормативів, найпоширенішими є: редагування текстів, робота 3 деформованими текстами, робота в парах (переклад - взаємоконтроль, самоконтроль), морфологічні задачі (як правильно побудувати?), вправи на закінчення фрази, речення, добір фразеологічних синонімів, антонімів. Наприклад:

- Розв'яжіть морфологічну задачу. Визначте рід поданих іменників: рояль, тюль, толь, шампунь, степ, ступінь, біль. вуаль, кір, насип, Сибір, дріб, нежить, нероба, пил, блакить, собака, птах, куліш, санаторій, берет, злочинеиь, сад, вікно. Подані іменники поставте в родовому відмінку однини.

- Відредагуйте речення, виправивши помилки у вживанні числівників: Скільки зараз годин? Зараз година ночі. Я встав у вісім годин ранку. Зараз без п'ятнадияти шість. Зараз шість годин. Коли трапилася пожежа, він вискочив на вулицюю в одній білизні. Батьки пішли в гості, а діти залишилися одні. При відсутності старости групи, його замінює хтось другий. Він прийшов в половині четвертого.

- Розкрийте дужки, уживаючи іменники у формі кличного відмінка: Здрастуйте (пані Надія). Де ви відпочивали влітку, (кум Ігор)? Вибачте, (пан директор), я незгоден працювати після уроків. У вашій доповіді, (пан Петренко), є багато иікавих фактів.

Висновки і перспективи подальших розвідок. Писемне мовлення учасника $3 \mathrm{HO}$ має грунтуватися на нормах літературної мови. Автор власного висловлення повинен знати мовні норми, уникати їхнього порушення у створеному тексті, оскільки вони кваліфікуються як помилки, що свідчать про недоформованість мовленнєвої компетентності тестованого, а тому вможливлюють зниження оцінки учасника за критеріями «мовного оформлення». Спираючись на ідеї В. О. Сухомлинського, ми 
переконалися, що українська мова має виразні індивідуальні риси на різних мовних ярусах, тому анормативи є свідченням недостатнього опанування мовних норм.

Верифікація мовних помилок у цій розвідці дала змогу виявити високий рівень таких помилок в учнівських роботах. Отже, основні причини появи анормативних одиниць - це незнання норм сучасної української літературної мови, потужний вплив російської мови, а також дія аналогії до інших форм. Щоб правильно орієнтувати здобувачів освіти у виборі мовних засобів та вмілому застосуванні, учитель/викладач має бути добре обізнаним із сучасними процесами розвитку мови, труднощами, які виникають у засвоєнні учнями/студентами знань про норми української літературної мови, ефективно застосовувати різноманітний комплекс мовних вправ У цій розвідці ми лише окреслили основні напрями роботи в контексті ідей педагогіки В. О. Сухомлинського. На наш погляд, конкретизація ряду положень унормованості висловлень учнів/студентів є темою окремого більш широкого дослідження.

\section{СПИСОК ВИКОРИСТАНИХ ДЖЕРЕЛ}

Булаховський, Л. (1947). Виникнення і розвиток літературних мов. Мовознавство. T. 4. C. 147.

Великий тлумачний словник украӥнської мови. (2005). В.Т.Бусел.(ред). Київ; Ірпінь: ВТФ «Перун». $1728 \mathrm{c}$.

Вихованець, І. (2012). Розмовлясмо украӥнською: мовознавчі етюди. Київ: Унів. вид-во «Пульсари». $160 \mathrm{c}$.

Волошин, К. (2003). Педагогічна система В. Сухомлинського. Наукові записки ТДПУ ім. В. Гнатюка: Педагогіка. 2003. № 11. С. 17 - 18.

Грона, Н. (2017). Підготовка студентів педагогічних коледжів до формування у молодших школярів текстотворчих умінь: монографія. Ніжин : ПП Лисенко М. М. $592 \mathrm{c.}$

Експрес-порадник учителя НУШ: короткий термінологічний словник (2019). укл. М. Греб, Н. Грона. Ніжин : НДУ ім. М. Гоголя. 48 с.

Заволока, С. (1979). Спогади про Сухомлинського. Київ : «Радянська школа». 254c.

Омельчук, С. (2019). Сучасна українська лінгводидактика: норми в термінології $i$ мовна практика фахівців: монографія. Київ: Видавничий дім «Києво-Могилянська академія». $356 \mathrm{c.}$

Словник лінгвістичних термінів (1985). К.: Вища школа. 360 с.

Сухомлинський, В. (1977). Вибрані твори : в 5 т. Київ : Вид-во «Радянська школа». Т.3: Рідне слово. 669 с.

Сухомлинський, В. (1979). Павльшская средняя школа: обобщение опыта учебновоспитательной работы в сельской средней школе. 2-е изд. Москва: Просвещение. 396с.

\section{REFERENCES}

Bulakhovskyi, L. (1947). Vynyknennia i rozvytok literaturnykh mov [Developmant of the Literary Languages]. Movoznavstvo. T. 4. S. 147. (in Ukrainian)

Velykyi tlumachnyi slovnyk ukrainskoi movy (2005). [Great Explanatory Dictionary of the Ukrainian Language]. V.T.Busel.(red). Kyiv; Irpin: VTF "Perun". 1728 s. (in Ukrainian)

Vykhovanets, I. (2012). Rozmovliaiemo ukrainskoiu: movoznavchi etiudy [Speak Ukrainian: Linguistic Essays]. Kyiv: Univ. vyd-vo "Pulsary". 160 s. (in Ukrainian)

Voloshyn, K. (2003). Pedahohichna systema V. Sukhomlynskoho. [Pedagogical System of V.Sukhomlynskyi]. Naukovi zapysky TDPU im. V. Hnatiuka: Pedahohika. 2003. №11. S. 17 - 18. (in Ukrainian)

Hrona, N. (2017). Pidhotovka studentiv pedahohichnykh koledzhiv do formuvannia u molodshykh shkoliariv tekstotvorchykh umin: monohrafiia. [Training of Students of Teachers' Colleges for Formation Text-Making Skills in Junior Schoolchildren: monograph]. Nizhyn : PP Lysenko M. M. 592 s. (in Ukrainian) 
Ekspres-poradnyk uchytelia NUSh: korotkyi terminolohichnyi slovnyk. (2019). [Express Advisor to the Teacher of the New Ukrainian School: Short Glossary] ukl. M. Hreb, N. Hrona. Nizhyn : NDU im. M. Hoholia. 48 s. (in Ukrainian)

Zavoloka, S. (1979). Spohady pro Sukhomlynskoho. [Memories about Sukhomlynskyi] Kyiv : "Radianska shkola". 254 s. (in Ukrainian)

Omelchuk, S. (2019). Suchasna ukrainska linhvodydaktyka: normy v terminolohii $i$ movna praktyka fakhivtsiv: monohrafiia [Modern Ukrainian Linguodidactics: Standards in Terminology and the Language Practice of Specialists: monograph]. Kyiv: Vydavnychyi dim "Kyievo-Mohylianska akademiia". 356 s. (in Ukrainian)

Slovnyk linhvistychnykh terminiv. (1985). [Dictionary of Linguistic Terms]. Kyiv: Vyshcha shkola. 360 s. (in Ukrainian)

Sukhomlynskyi, V. (1977). Vybrani tvory : v 5 t. [Selected Works: in 5 vol]. Kyiv : Vydvo "Radianska shkola". T.3: Ridne slovo. 669 s. (in Ukrainian)

Sukhomlynskyi, V. (1979). Pavlyshskaia sredniaia shkola: obobshchenie opyta uchebno-vospitatelnoi raboty $v$ selskoj srednej shkole [Pavlysh Secondary School: Generalization of the Experience of Educational Work in a Village Secondary School].2-e yzd. Moskva: Prosveshcheniye. 396 s. (in Russian)

\section{OWN SPEECH UTTERANCE: LANGUAGE STANDARDIZATION IN THE CONTEXT OF V. O. SYKHOMLYNSKYI'S IDEAS}

Nataliia Hrona

Doctor of Sciences (in Pedagogy), Head at the Cyclic Commission of Ukrainian Teachers, Pryluky Humanities-Pedagogical College named after Ivan Franko, Pryluky, Ukraine ORCID:0000-0003-2578-2665 e-mial: natashagrona@ukr.net

Abstract. The article is focused on the relevance of V. O. Sukhomlynskyi's pedagogical ideas in the context of the problem of adherence to language standards in own speech utterance of the participants of the external independent evaluation. It is emphasized the necessity and importance of using the views of the great teacher in studying Ukrainian. V. Sukhomlynskyi recommends to work much and thoughtfully for a word to love in children' creativity, in communication; he regarded it is as one of the conditions of general and pedagogical culture of the school life.

The author considers that the creation of perfect texts is a complex analytical and synthetic process, aimed to achieve the result of cognitive activity.

It has been proved that the process of preparing to the creation of own speech utterance is useless without practical activities of students in learning and improving language standards. To avoid making vocabulary and grammar mistakes in text-reflections it is necessary to use different language exercises.

To orient students in choosing language tools, a teacher must be knowledgeable with modern language development processes, difficulty, that arises in students during their assimilation of knowledge about the Ukrainian literary language standards, skillfully apply a wide range of teaching methods.

Scientific research made it possible to highlight leading areas of work for developing the standards of literary language that is the basic condition for the implementation of the most important language function - communicative.

Due to ideas of V. O. Sukhomlynsky it has been confirmed that Ukrainian has its own unique characteristics therefore, a non-standard indicates a lack of mastery of language norms.

Keywords: pedagogical ideas of V.Sukhomlynskyi, independent external evalution, personal speech, text, language standards, non-standards, vocabulary and grammar mistakes, language exercises.

Стаття надійшла до редакиії 30.07.2019 p. 